\title{
Conversos versus Recusants: Shaping the Markers of Difference (1570-1680)
}

\author{
Natalia Muchnik*
}

In 1582, in Naburn, a town near York, England, Elizabeth Coulson, suspected of crypto-Catholicism, was caught hiding her Protestant communion bread, claiming that "a pain in her side and a cough" were preventing her from swallowing it. ${ }^{1}$ A few decades later, in 1619, the conversa Catarina Fernandes was burned alive by a mob in Saint-Jean-de-Luz, France, after she was seen concealing her communion wafer instead of consuming it. The event prompted the town's remaining crypto-Jews to flee. Those efforts to avoid conforming to the dominant religion illustrate the tension between simulation and dissimulation that permeated the lives of English crypto-Catholics (known as Recusants), ${ }^{2}$ following the English religious reformation in the sixteenth century, and those of Spanish crypto-Jews or Marranos, ${ }^{3}$ in this case in exile in

* I wish to thank John Angell and Sebastien Le Pipec for their assistance in translating this article.

1 John Cedric H. Aveling, Catholic Recusancy in the City of York, 1558-1791 (London: Catholic Record Society, 1970), 197. Elizabeth was employed as a maid in the Manor House of the Palmes who remained Catholic.

2 See, inter alia, John Cedric H. Aveling, The Handle and the Axe: The Catholic Recusants in England from Reformation to Emancipation (London: Blond and Briggs, 1976); John Bossy, The English Catholic Community, 1570-1850 (London: Darton, Longman and Todd, 1975); Lisa McClain, Lest We Be Damned. Practical Innovation and Lived Experience among Catholics in Protestant England, 1559-1642 (New York: Routledge, 2004); Michael Mullet, ed., English Catholicism: 1680-1830, 6 vols. (London: Pickering \& Chatto, 2006); Michael Questier, Conversion, Politics, and Religion in England, 1580-1625 (Cambridge: Cambridge University Press, 1996); Peter Lake and Michael Questier, The Antichrist's Lewd Hat. Protestants, Papists and Players in Post-Reformation England (New Haven: Yale University Press, 2002); Alexandra Walsham, Church Papists. Catholicism, Conformity and Confessional Polemic in Early Modern England (London: Boydell \& Brewer, 1999 [1993]).

3 See, inter alia, Julio Caro Baroja, Los judíos en la España moderna y contemporánea, 3 vols. (Madrid: ISTMO, 2000 [1961]); David M. Gitlitz, Secrecy and Deceit. The Religion of the CryptoJews (Albuquerque: University of New Mexico Press, 2002 [1996]); David L. Graizbord, Souls in Dispute: Converso Identities in Iberia and the Jewish Diaspora, 1580-170o (Philadelphia: University of Pennsylvania Press, 2004); Richard L. Kagan and Philip D. Morgan, eds., Atlantic Diasporas: Jews, Conversos, and Crypto-Jews in the Age of Mercantilism, 1500-1800 (Baltimore: The Johns Hopkins University Press, 2008); Charles Meyers and Norman Simms,

(C) NATALIA MUCHNIK, 2019 | DOI:10.1163/9789004392489_004

This is an open access chapter distributed under the terms of the prevailing CC-BY-NC License at the time of publication. 
France. Both groups were subject to harsh repressive measures and forced to worship in secret, but they also displayed a remarkable degree of internal religious and socio-economic diversity.

Indeed, at a time when religion was a significant determiner of social position and socio-cultural practices, these dissident groups possessed an impressively wide array of expressions of belonging. This is particularly true if we cease to focus on the period's celebrated and heroic figures who were doomed to the gallows or the stake because they refused to compromise. Historiography has long concentrated on these cases and neglected such groups as the "Church Papists" who sometimes participated in Anglican practices while proclaiming themselves Catholics. The majority of these religious "deviants" held unstable beliefs and participated in changeable worship practices, but they often remained deeply attached to a sense of community. ${ }^{4}$ They are usually defined by negative attributes as well as positive practices, because dissimulation and simulation tended to blur boundaries, even between ostensibly wellestablished categories. Because dissimulation shaped their social and religious lives, Marranos and crypto-Catholics shared certain features with the secret societies studied by Georg Simmel ${ }^{5}$ in terms of the centrality of private space and family, language codes, and a dialectical relationship with the types of repression that shaped their allegiances. Secret life also transformed roles in religious practices and induced ritual displacements in ways that went beyond mere adaptations to risk or to the lack of normative religious institutions.

As this essay will argue, secrecy helped both these minorities to function as groups despite internal diversity. The elasticity of the groups' religious practices clearly contributed to the emergence of new methods of worship and the creation of new ritual objects. It ultimately appears that Marranos

eds., Troubled Souls: Conversos, Crypto-Jews, and Other Confused Jewish Intellectuals from the Fourteenth through the Eighteenth Century (Hamilton: Outrigger Publishers, 2001); Israël S. Révah, Des marranes à Spinoza (Paris: Vrin, 1995); Nathan Wachtel, La foi du souvenir. Labyrinthes Marranes (Paris: Éditions du Seuil, 2001); Yirmiyahu Yovel, The Other Within. The Marranos. Split Identity and Emerging Modernity (Princeton, NJ: Princeton University Press, 2009).

4 Natalia Muchnik, De paroles et de gestes. Constructions marranes en terre d'Inquisition (Paris: Éditions de l'EHESS, 2014); Michael Questier, "Conformity, Catholicism and the Law," in Conformity and Orthodoxy in the English Church, c. 1560-1660, ed. Peter Lake and Michael Questier (Woodbridge: Boydell, 200o), 237-62, and Alexandra Walsham, "England's Nicodemites: Crypto-Catholicism and Religious Pluralism in the Post-Reformation Context," in The Adventure of Religious Pluralism in Early Modern France, ed. Keith Cameron, Mark Greengrass, and Penny Roberts (Oxford: Peter Lang, 2000), 292-94.

5 Georg Simmel, "The Sociology of Secrecy and of Secret Societies," American Journal of Sociology 11 (1906): 441-98. 
and crypto-Catholics were closely linked to their respective diasporas and that they existed as cohesive groups not only because their members shared religious practices but also because of the diasporic culture of martyrdom. As martyrs for the faith, they were thus fully integrated into the diaspora, despite the negative interpretations of their dissimulation and simulation strategies.

\section{1 \\ Secrecy as a Way of Life}

Despite their similarities, Marranos and Recusants (and Church Papists) have seldom been the object of joint investigation by researchers. Of course, there were important differences between the two groups, especially in terms of their respective socio-political contexts and the intensity of the repression that they experienced. Many Marranos were conversos who had been stigmatized by blood purity statutes that divided the Hispanic society between Old and New Christians from the 1550 on onward. ${ }^{6}$ The Marranos, however, turned the stigmatization of their blood into an asset, as the sign of a sort of ethnic superiority. ${ }^{7}$ But there was no analogous stigmatization or "pride of lineage" among the Recusants, who-with the exception of priests-endured milder forms of repression. Although crypto-Judaism is not a consequence of the Inquisition, as some historiographical accounts have suggested, ${ }^{8}$ repression is, in actuality, both a destructive and a creative force.

6 See, inter alia, Albert Sicroff, Les controverses des statuts de pureté de sang en Espagne (Paris: Didier, 1960); Juan Hernández Franco, "El pecado de los padres: construcción de la identidad conversa en Castilla a partir de los discursos sobre limpieza de sangre," Hispania 64 (2004): 515-42; Ruth Pike, Linajudos and Conversos in Seville. Greed and Prejudice in Sixteenth- and Seventeenth-Century Spain (New York: Peter Lang, 200o); and François Soyer, Popularizing Anti-Semitism in Early Modern Spain and Its Empire. Francisco de Torrejoncillo and the Centinela contra Judios (1674) (Leiden: Brill, 2014).

7 Miriam Bodian, 'Men of the Nation': The Shaping of Converso Identity in Early Modern Europe," Past and Present 143 (1994): 48-76, and "Hebrews of the Portuguese Nation: The Ambiguous Boundaries of Self-Definition," Jewish Social Studies 15, no. 1 (2008): 66-80; David Graizbord, "Religion and Ethnicity Among 'Men of the Nation': Toward a Realistic Interpretation," Jewish Social Studies 15, no. 1 (2008): 32-65; and Natalia Muchnik, "Being Against, Being With: Marrano Self-Identification in Inquisitorial Spain (16th-18th c.). An Essay," Jewish History 25 (2011): 153-74.

8 We will not comment further on the controversies raised by António J. Saraiva's (The Marrano Factory. The Portuguese Inquisition and Its New Christians, 1536-1765 [Leiden: Brill, 2001]) and Benzion Netanyahu's works (The "Marranos" of Spain from the Late XIVth to the Early XVIth Century [New York: American Academy for Jewish Research, 1966] and The Origins of the Inquisition in Fifteenth-Century Spain [New York: Random House, 1995]). 
Because of highly variable ritual practices and group configurations, the sense of religious belonging — or self-definition — was more determined by social and identity-related variations. ${ }^{9}$ Like the Recusants, the Marranos, and to an even greater extent the Church Papists, did not have clearly established group boundaries. Bonds were formed through encounters, but also through reputation and hearsay. It is therefore difficult to establish how many there were, in part because numbers fluctuated according to the intensity of repression. Starting in the 1570s, the arrivals of missionaries from seminary colleges on the Continent helped maintain or even reactivate crypto-Catholicism. Likewise, waves of immigration of Portuguese conversos to Spain from the 1580 os (especially during the Iberian Union) ${ }^{10}$ revived crypto-Judaism, which had worn away in Spain. It is nevertheless important to stress the importance and visibility of crypto-Catholics, who counted in the tens of thousands throughout England, living generally in the countryside ${ }^{11}$ when Spanish Marranos consisted of no more than a handful of families usually concentrated in urban areas.

Moreover, beliefs and practices could also vary in the course of a single individual's life or depending on the social environment. ${ }^{12}$ This was particularly the case among crypto-Jews, especially the "Portuguese," many of whom were traders and were highly mobile, unlike Recusants, who often appear to have been more rooted in their local communities, especially the landed gentry around whom crypto-Catholic circles revolved. Another factor is that the sources containing this kind of information are biased, whether judicial documents, which were double-filtered through interrogations and court recorders' own prejudices and categories, as well as apologetic writings from the two diasporas.

Lucy E.C. Wooding, Rethinking Catholicism in Reformation England (Oxford: Clarendon Press, 2003), 3-6. We will not go over the concept of identity and the problems of its use here; they gave rise to a vast literature. See, inter alia, Rogers Brubaker and Frederick Cooper, "Beyond 'Identity', in Rogers Brubaker, Ethnicity without Groups (Cambridge, MA: Harvard University Press, 2004), 28-63; Craig Calhoun, ed., Social Theory and the Politics of Identity (Oxford: Blackwell, 1994); Carmel Camilleri et al., eds., Stratégies identitaires (Paris: PUF, 1990); Anthony Giddens, Modernity and Self-Identity: Self and Society in the Late Modern Age (Cambridge: Polity Press, 1991).

10 See, inter alia, Rafael Carrasco, "Inquisición y judaizantes portugueses en Toledo (segunda mitad del siglo XVI)," Manuscrits 10 (1992): 41-6o and "Preludio al "Siglo de los portugueses.' La Inquisición de Cuenca y los judaizantes lusitanos en el siglo XVI," Hispania 47 (1987): 503-59.

11 There were about forty thousand Catholics in England at the beginning of the seventeenth century and approximately sixty thousand in 1640 according to Bossy, The English Catholic Community, 191-93 and 422 and Walsham, Church Papists. Catholicism. 
There was a significant mirroring effect produced by the broader society in the identification processes and cohesive elements found in these clandestine communities. Indeed, in both cases, religious minorities were stigmatized because of their so-called lack of loyalty toward the Church and the monarchy; heresy was considered a crime of lèse-majesté. They were often considered to be traitors who were acting on behalf of foreign powers. Conversos were thought to be helping the "rebels" in Portugal or in the Low Countries, where many conversos had relatives. The Recusants, on the other hand, were perceived as being aligned with the Pope and the Spanish monarchy, particularly during armed conflicts such as the Anglo-Spanish War (1585-1604). In the case of cryptoJews, their reputation as outsiders was accentuated by the issue of ethnicity, as well as by the stateless status typically attributed to Jews. For the Recusants, this phenomenon was related to the highly political nature of Anglicanism and to the latent fears crystallized along the alleged "plots" to assassinate the reigning monarch (Gunpowder Plot in 1605, Popish Plot in 1678, etc.). The social environment of the Recusants thus resembled an enclave that was in permanent resistance to State authority and that existed outside the law..$^{13} \mathrm{~A}$ similar pattern was observable among conversos, who were suspected-often accurately — of participating in smuggling, a significant source of loss for the Spanish monarchy's tax revenues. The international circulation of individuals, objects, and ideas emphasized their image of foreignness. They were perceived as being simultaneously similar and different, triggering the vague sensation of "troubling strangeness" described by Freud. ${ }^{14}$

Repression clearly played a critical role in mobilizing hidden religions and in the formation of secret societies. Solidarity, codes, and initiation rituals bound groups together, while conferring a sense of superiority. ${ }^{15}$ Insiders could

13 Julian Yates, "Parasitic Geographies: Manifesting Catholic Identity in Early Modern England," in Catholicism and Anti-Catholicism in Early Modern English Texts, ed. Arthur F. Marotti (Houndsmills: Macmillan Press, 1999), 63-65.

14 Frances E. Dolan asserts that, "by remaining in, or returning to, England, Catholics troubled the very notion of Englishness," in "Gender and the 'Lost' Spaces of Catholicism," The Journal of Interdisciplinary History 32 (2002): 643. See also Alison Shell, Catholicism, Controversy and the English Literary Imagination, 1558-1660 (Cambridge: Cambridge University Press, 1999).

15 Simmel, "The Sociology of Secrecy," 464: "subjective possessions of the most various sorts acquire a decisive accentuation of value through the form of secrecy, in which the substantial significance of the facts concealed often enough falls into a significance entirely subordinate to the fact that others are exclued from knowing them"; 486: "As a consequence of the fact that those who want to distinguish themselves enter into combination, there results an aristocracy which strengthens and, so to speak, expands the self-consciousness of the individuals through the weight of their sum." 
enter the community and become acquainted with group members and, because the collectivity was of a religious nature, they could appear to be both inspired by true faith and among the elect, secure in the knowledge of sharing a Messianic destiny. Both Recusants and Marranos formed a single body in the Pauline sense of the term, as summarized by formulas such as "all are one" (todos son uno) that were often used to describe the inter-dependent relationships among crypto-Jews. ${ }^{16}$

Shared meals also provided significant opportunities to express group solidarity, as described below by the Jesuit Robert Persons in August 1581: "Sometimes when we are sitting at table quite cheerfully [...] if it happens that someone rings at the front door a little more insistently than usual so that he can be put down as an official, immediately [...] all stand to attention, stop eating, and commend themselves to God [...] and if it turns out that there is no danger, after the scare they have had, they become still more cheerful. It can truly be said of them that they carry their lives always in their hands."17 And each in the hands of the other one might add. Here we find the cohesion instituted by a shared fear and the communion over a meal that symbolizes the cosubstance of the participants within the community; "the group is a mouth."18

Inside these secret societies, certain individuals played significant roles. In Spain, this was true of physicians and other professionals who were involved in traveling such as traders, because mobility permitted to maintain networks and spread information. Because of the aura that surrounded doctors due to their medical skills, they possessed a certain authority in the religious lives of crypto-Jews. Their mobility enabled them to operate as the keepers of ceremonies and rituals and, in effect, as proselytizers, thus ultimately contributing to the territorial organization of Marranos communities. Physicians were also able to keep the members of family networks in Spain and throughout the diaspora informed about one another, this being the basis of a Marrano "virtual diaspora" that coexisted with the real diaspora. ${ }^{19}$ Recusant missionaries played similar roles because their mobility and positions within an itinerant

16 Muchnik, De paroles et de gestes, 57-60.

17 Robert Persons's letter to father Alphonsus Agazzari, rector of the English College in Rome, is printed in Letters and Memorials of Father Robert Persons, SJ, vol. I (to 1588), ed. Leo Hicks (London: Catholic Record Society, 1942), 86.

18 Didier Anzieu, Le groupe et l'inconscient: l'imaginaire groupal (Paris: Dunod, 1999 [1975]), 99. See in particular Simmel, "The Sociology of Secrecy," 475: "the fact that the spring of knowledge flowed only from within the society [...] attached the individual member with unique intimacy to the community. It gave him the feeling that if he were detached from this substance, he would lose his own, and would never recover it elsewhere."

Muchnik, De paroles et de gestes, 210-14. 
religious practice ensured a degree of cohesiveness among scattered clandestine communities. The stately homes of the Catholic gentry harbored priests, who became chaplains for their hosts and neighbors. Because they were able to come and go freely, traders were also ideal passeurs who were able to conceal books and other religious items amid their cargoes. They were also effective because their stores, which sometimes distributed religious objects, also functioned as communication nodes for nearby communities. A Fleet Street wholesaler named James Tailor who lived in the Catholic neighborhood of London, for example, housed priests during the late sixteenth century. He also acted as a messenger between the English Catholic elite and the diaspora and helped disseminate books that were published abroad. ${ }^{20} \mathrm{~A}$ similar case was that of Fernando Montesinos, a well-known converso trader who was born in Portugal and served as an asentista (financier-lender) to Philip IV of Spain, and departed for Antwerp in 1656 after undergoing a second trial at the hands of the Inquisition. Montesinos played a key role in the crypto-Jewish community by distributing significant amounts of alms among the poor and helping convey news to and from their relatives in the diaspora. ${ }^{21}$

Geographical mobility and dissimulation in public spaces also highlighted social categories that were frequently marginalized. Because of the secrecy and sanctification of the home, for example, women's visibility was enhanced as they adopted more prominent roles in worship ceremonies, although it would be an over-simplification to argue that there was a clear distinction drawn between a masculine public sphere and private, feminine spaces. ${ }^{22}$ Evidence for the argument that women occupied significant positions in Marrano communities can be found in the many charges of crypto-Judaism brought against women during the sixteenth and the seventeenth centuries. In the case of the Recusants, women martyrs celebrated in the martyrologies published by the Recusant diaspora provide similar evidence. In fact, the legal status endowed to women allowed them to enjoy certain forms of freedom-for

$20 \quad$ McClain, Lest We Be Damned, 169-71.

21 Bernardo J. López Belinchón, Honra, libertad y hacienda (Hombres de negocios y judios sefardíes) (Alcalá de Henares: Universidad de Alcalá, 2001); James C. Boyajian, Portuguese Bankers at the Court of Spain, 1626-1650 (New Brunswick, NJ: Rutgers University Press, 1983), 56; and Markus Schreiber, Marranen in Madrid, 1600-1670 (Stuttgart: Franz Steiner, 1994).

22 See, inter alia, Renée Levine Melammed, Heretics or Daughters of Israel? The Crypto-Jewish Women of Castile (Oxford: Oxford University, 1999), and Natalia Muchnik, "De la ville inquisitoriale à la ville de tolérance: identités féminines judaïsantes en Europe occidentale (XVII ${ }^{\mathrm{e}}$ siècle)," Annales de Bretagne et des pays de l'Ouest 113 (2006): 29-42. 
instance, until 1593, they could not be sentenced to paying fines. ${ }^{23}$ One example is the home of Margaret Clitherow, who was executed in 1586, and whose life and martyrdom were celebrated by her fellow Recusants. A manuscript relating her story, which circulated among Recusants, ${ }^{24}$ reported that she possessed an altar, a chalice, numerous books, and that her home became known as the place to hear mass in York between 1570 and 1580. One of Clitherow's acquaintances named Dorothy Vavasour, a doctor's wife, housed pregnant women and young mothers and helped them to baptize their children. ${ }^{25}$

The singular role played by such women in clandestine practices was reflected in the imaginaries of the two communities, which centered on two important biblical figures, Esther and Mary. On the one hand, Esther, whose name derives from the word seter (secret), was the quintessential cryptoJudaic woman and an emblem of Marrano destiny. She had concealed her Jewish identity, but when she learned that the lives of the Empire's Jews were endangered, she intervened on their behalf. By making a virtue of dissimulating her Jewishness - which was highly criticized by the diaspora - and turning it into an instrument of salvation, Esther legitimized or even transfigured the Marrano experience. It was for this reason that the fast that honors her, a relatively minor festival in normative Judaism, became an important holiday for the crypto-Jews. Similarly, the Recusants represented the figure of Mary as a warrior and the protector par excellence of English Catholics for her actively intervening on their behalf, especially through the rosary. This image of Mary contrasted both with the contemporary vision of docility and humility promoted by Rome and the more contemplative, passive image of Mary that dominated in the Middle Ages. ${ }^{26}$

23 In fact, prior to 1593, married women legally possessed neither property nor money. See Walsham, Church Papists, 78-81; Elizabeth Ferguson, "The Role of Women in the Survival of Catholicism in Post-Reformation Lancashire and Yorkshire, 1559-1603," Master's thesis, Carleton University (Ontario), 2006, 10; Mary Rowlands, "Recusant Women (1560-1608)," in Women in English Society, 1500-180o, ed. Mary Prior (London: Methuen, 1985), 114-15; Roland Connelly, The Women of the Catholic Resistance in England 1540-1680 (Durham: Pentland Press, 1997).

24 Anne Dillon, The Construction of Martyrdom in the English Catholic Community, 1535-1603 (Aldershot: Ashgate, 2002), 277-322, and Peter Lake and Michael Questier, The Trials of Margaret Clitherow. Persecution, Martyrdom and the Politics of Sanctity in Elizabethan England (London: Continuum, 2011).

25 Ferguson, The Role of Women, 53.

26 McClain, Lest Be Damned, 103-12, and Donna Spivey Ellington, From Sacred Body to Angelic Soul. Understanding Mary in Late Medieval and Early Modern Europe (Washington, DC: Catholic University of America Press, 2001), 142-87. 
Like women, the poor also acquired a specific function in the community by begging in the streets and receiving alms from the religious community, an activity that enabled them to spread information within the group. It is not surprising that a certain Darby Bantre, an Irishman arrested in 1639 in Euston, Northeast London, for being in possession of thirty rosaries, five copies of the Office of the Blessed Virgin, and over three pounds in change (quite a significant sum), had disguised himself as a beggar. Whether he was genuinely poor or not, he operated as a supplier of Catholic ritual objects from the Continent. ${ }^{27}$ Among Marranos, fasting was an essential aspect of their religious life, and the poor were paid to fast for other members of the community. Most professional fasters were women, often widows, who ensured collective salvation, in the wake of Esther. In Madrid, those professional fasters were distributed according to the neighborhoods they lived in. In the mid-seventeenth century, Beatriz Rodríguez, the widow of a silversmith, and her daughters Ana, Escolastica, and Isabel, as well as Leonor Gómez, another widow, belonged to the same milieu and frequented the same houses. They were required to fast, for example, for the sake of deceased's souls, so that a sick child may recover and, more generally, on occasion of the main holidays of the Mosaic calendar. That is why, when the converso Manuel Cortizos, asentista of Philip IV, died, Leonor received some reales to fast for the sake of his soul. ${ }^{28}$ Orphan girls were also liable to be professional fasters because they had little dowries or no dowry at all and, therefore, were less likely to get married. By traveling from house to house, these widows acted as vectors of group identity and cohesion by maintaining relationships across the community. At the same time, being paid was thought to dissuade them from denouncing community members to the Inquisition.

Repression and secrecy shaped the basic social organization of the Recusant and Marrano communities, increasing the prominence of certain individuals, either real or spiritual. These forces also directly influenced individual beliefs and practices. But because of the absence of normative institutions, practices were ever flexible, achieving a form of legitimacy through creativity.

One extremely significant difference between the two groups resides in the fact that the Recusants defined themselves as Christians and lived in a Christian environment. Therefore, in comparison to the Marranos, the Recusants had

27 McClain, Lest We Be Damned, 92.

28 Madrid, Archivo Histórico Nacional [AHN], Inquisition Section [INQ], Book 1113. 
considerably more room to maneuver and a wider array of resources that they could either exploit or distort. Nevertheless, the example of the coexistence of Lutherans and Calvinists within the Holy Empire confirmed that similarity paradoxically compelled the two faiths to emphasize their differences. The fact remains that in both cases, adaptation ruled daily life.

The necessity of occasionally participating in official religious activities, the criticisms of the diaspora notwithstanding, entailed a certain amount of compromise and negotiation in terms of social imperatives. In England, for example, heads-of-household and elder sons were often required to be seen conforming to social conventions in public as a way of preserving their property as well as their dignity. For example, a Sussex gentleman named Garret Kempe encouraged his eldest son to conform "and did very often urge and persuade him to go to the protestant churches,"29 while at the same time discouraging his spouse and younger children from participating in ceremonies at the temple. Similarly, the strong preference for a spouse of the same faith and the constraints of clandestine living often tended to dissolve in the face of socio-economic imperatives. Lorenzo Angel and his wife Gracia Rola, for example, were crypto-Jews from Badajoz who raised their children within the faith but who gave their three daughters in marriage to Old Christian hidalgos in exchange of significant dowries and false evidence of pure blood, while preferring on the other hand that their son married a crypto-Jewish woman. The couple and two of their daughters were later tried and convicted by the Holy Office in 1569.30

The absence of a central authority to ensure conformity with religious norms, at least not always in the case of the Recusants, meant that individuals were masters of their own practices in the eyes of the clandestine group. Depending on possibilities, obligations, and the rites that individuals considered important, they adopted traditions that developed over time depending on the possibilities and contacts they had. An individual might adopt ritual objects and practices that were not common in the Jewish or Catholic orthodoxies, but that fitted life in clandestinity, such as food habits among the Marranos. From this perspective, the religiosity of these groups appears highly creative and quite remote from the syncretism or spiritual and ritual impoverishment long attributed to Marrano practices by historiography and interpreted as signs of assimilation. Marranos were clearly aware of the imperfections of their rituals from an orthodox point of view, but they seem to have fully

29 Quoted in Walsham, Church Papists, 78.

3o Jaime Contreras, "Criptojudaísmo en la España moderna. Clientelismo y linaje," Areas 9 (1988): 91 . 
accepted these divergences. In 1619, when Ana Mendez described how she and her family in Monsanto, Portugal, and later in Jativa (near Valencia), celebrated the "great day" [Yom Kippur], she recorded that "everyone had to pray what he knew of the Law of Moses."31 But this flexibility did not exclude adopting a high degree of strictness: Marrano fasts, for example, could be extremely rigorous, and crypto-Jews were scrupulous in thoroughly enacting any slightest ritual gesture.

Adaptation and ritual invention appear to have been encouraged by the diaspora, whose members adopted an understanding attitude while officially remaining critical. At least, this was the case for those who had once been forced to hide or had been led to do so under certain circumstances. Former Marranos converted to Judaism in the diaspora, but who were visiting Spain for business, provided very specific instructions about how to conduct ceremonies with whatever means at one's disposal. In 1648-1649, while staying in Andujar for business, Manuel Díaz Pimentel, a New Jew from Pisa or Livorno, was often questioned about Jewish rituals by the conversos. He gave many specifics on how Judaism was practiced in Italian communities, always trying to adapt his discourse to his audience though, and providing them with the tricks to perform the rituals, especially those concerning food and food preparation, so that the Inquisition's suspicion should not be aroused. Thus, "in Spain, to eat a partridge who has been shot with an arquebus, it has to be roasted and its inside greased with oil because that is how you can compensate the fact that its throat has not been slit." Likewise, on Friday evening, they "had to eat as much good food [as] they could: in Spain, fish, in order to conceal [from the Inquisition]; in Italy, France, Flanders or other places, where one can judaize freely, [one could eat] meat prepared according to the [Jewish] usage and observance." 32

Moreover, English missionaries' instructions clearly took the need for secrecy and the absence of priests into account, particularly from the 1590s onward. The highly popular A Catechisme or A Christian doctrine necessarie for children \& the ignorant people [...] (Louvain, 1568) by Laurence Vaux, a refugee on the Continent, which forbade hiding one's religious affiliation and recommended to attend mass every Sunday and take communion regularly, stood

\footnotetext{
31 "[A]bia cada uno de reçar lo que sabia," in AHN INQ, Legajo 164 (4).

32 "[P]ara comer la perdiz siendo muerta al alcabuzazo en españa ha de ser asada y untada con açeyte por de dentro porque deste modo dijo que se suplia el no estar degollada [...] havian de çenar todo lo que pudiesen de buenas comidas en España de pescado por disimular y en Ytalia o Françia y Flandes y otras partes donde libremente pueden Judayzar carnes dispuestas a su modo y observançia," in AHN INQ, Book 1112, fols. 31r-32V and Muchnik, De paroles et de gestes, 206-7.
} 
remarkably in contrast to A Shorte Rule of Good Life. To direct the devout christian in a regular and orderly course (Douai?, 1595) by the Jesuit missionary Robert Southwell (who was executed in 1595), which explained how to sanctify a house in one's mind, dedicating rooms to certain specific saints. The aim was not to mimic mainstream forms of worship, but to approximate the functions of the Catholic sacraments through content rather than through form. ${ }^{33}$ The teaching offered at seminary colleges encouraged flexibility and pragmatism, for missionaries - how to celebrate mass without the customary sacred utensils, taking confession from occasional reformed members, etc.-and worshippers alike. ${ }^{34}$ William Allen, the founder of the College of Douai, for example, urged English Catholics to join the Society of the Rosary in 1592-popularized by the Jesuits to develop interior devotion - relaxing the requirements for membership while ensuring its members of the indulgence associated with it. ${ }^{35}$

Other publications from the diaspora or printed locally on clandestine presses (in the case of the Recusants) ${ }^{36}$ provided instruments that were fit for secrecy, including the image of a rosary inserted into a prayer book that could replace the object itself. This was the case, for example, in the ... Instructions for the use of the beades, conteining many matters of meditacion or mentall prayer [...] where unto is added a figure or forme of the beades portrued in a Table [...] for the benefite of unlearned [...], which was published by John Bucke in Louvain in 1589 and which indicated the exact times when particular prayers should be recited. ${ }^{37}$ Similarly, the calendars published singly or as annexes to religious books for the Nação, listed the dates for major Jewish festivals and their equivalents in the Christian calendar, documents that were obviously less necessary in Jewish congregations. Nor were calendars uncommon among the English, including the example of a monthly calendar that indicated the Catholic celebrations and the Saint's days and the dates of the "moveable" festivals between 1743 and 1762 . This calendar was included in the sixth edition

33 McClain, Lest We Be Damned, 46-47, and 116, and Southwell, A Short Rule of Good Life, 128-33.

34 Peter Holmes, Resistance and Compromise. The Political Thought of the Elizabethan Catholics (Cambridge: Cambridge University Press, 1982), 117; McClain, Lest We Be Damned, 48; and Walsham, Church Papists, 65-66.

35 McClain, Lest We Be Damned, 98, and Ellington, From Sacred Body, 226-34.

36 Antony Francis Allison and David Morrison Rogers, A Catalogue of Catholic Books in English Printed Abroad or Secretly in England, 1558-1640 (Bognor Regis: Arundel Press, 1956), and Alfred C. Southern, Elizabethan Recusant Prose, 1559-1582. A Historical and Critical Account of the Books of the Catholic Refugees Printed and Published Abroad and at Secret Presses in England together with an Annotated Bibliography of the Same (Glasgow: Sands, 1950).

McClain, Lest We Be Damned, 93-95. 
of the Daily exercise of the devout Christian. Containing several moving practices of piety [...], by Thomas Vincent and Anselm Crowder, which was published in Dublin in 1743. Social networks were the place where such documents circulated both in Spain and in England. Such texts include the well-known Calendario de las fiestas que celebran los Hebreos, published by Juda Machabeu in Amsterdam in 1638; this ritual book's appendix was traced back to Malaga the following year. ${ }^{38}$ Other texts were hand-copied, relatively faithfully in the case of crypto-Catholics because they had access to learned scribes, or in more fragmented and blatantly highly altered ways among Spanish crypto-Jews.

Often small in size and brimming with practical details, these texts were easy to conceal and sometimes obviously designed for secret communities as the well-known post-face to the Orden de las oraciones del mes [...], by Menasseh ben Israel, printed in Amsterdam in 1636 proves: "[...] everything that is obligatory [...] is contained in this book, and so clearly in the notes, that not only those who are accustomed can very easily use them, but also those who are outside of the bosom [gremio], after having consulted it just once and by learning how it is organized."39

This desire for simplicity and clarity recalls the adjustments authorized by English authors like John Radford who explains in the preface to A Directorie Teaching the Way to the Truth in a Briefe and Plaine Discourse against the heresies of this time [...], which was printed clandestinely in 1605 , that he wrote "this little treatise, to inform especially an ignorant, and unlearned man: therefore I have accommodated my self as much as I could, to his understanding, using plain words, and now \& then often [sic] repetition of things that to the learned be not needfull." William Stanney, in A treatise of penance with an explication of the rule, and maner of living [...] of the Third Order of St. Frauncis [...] ordained for those which desire to leade a holy life, and to doe penance in their owne houses (Douai, 1617), also clearly changed Franciscan instructions to fit for the Recusants' situation. ${ }^{40}$ In fact, the diaspora appears to have accepted that the ritual ought to be changed for the sake of secrecy. For example, the

38 AHN INQ, Legajo $163(14)$.

39 "[Q]ue todo lo obligatorio [...] se contiene en este volumen, y con tanta claridad en las notas, que no solamente los que estan acostumbrados, con gran facilidad se podran aprovechar, mas aun los que estan fuera del gremio, haziendo una sola experiencia y conosciendo el orden," in Madrid, Biblioteca Nacional de España [BNE], R. 27290, fol. 548, and Carsten L. Wilke, "Un judaïsme clandestin dans la France du XVII ${ }^{e}$ siècle. Un rite au rythme de l'imprimerie," in Transmission et passages en monde juif, ed. Esther Benbassa (Paris: Publisud, 1997), 296.

$40 \quad$ Quoted in McClain, Lest We Be Damned, 49 . 
emphasis placed on the rosary among Recusants, which led ecclesiastical authorities to prescribe new norms like those included in Bucke's Instructions for the use of the beades.

These books, far from being mere emblems of belonging, acquired a certain degree of sacredness and played a role in the religious lives of the groups, both individually and collectively. A manifestation of this tendency to depend on books was the somewhat "bookish" character of the ritual knowledge and practices among the crypto-Jews of southwestern France. ${ }^{41}$ Among Recusants, the text became, to some extent, an intercessor, a vector of grace, which functioned almost like a virtual priest during services. ${ }^{42}$ Although we ignore how and to what extent such texts were read or what knowledge derived from them, they clearly widely served as objects of worship both in England and in Spain. They were also often endowed with a certain degree of holiness.

\section{3}

\section{New Places/New Objects}

The title of William Stanney's volume (A treatise of penance [...] to doe penance in their owne houses) reveals that secret turned the family home into the locus of the sacred. The Catholic gentry built chapels in their houses, while kitchens became central in Marrano homes because of the importance of their food habits. As Luisa de Carvajal y Mendoza, a Spanish Aristocrat helping the London Recusants in the 1610s, stated: "In the primitive Church the homes of the Christians were their churches and were the parishes of the others; in [Stuart] England, they are those of the Catholics." ${ }^{\text {43 }}$ Clandestine religious practice was therefore organized around domestic hubs and networks-of information, priests, etc.- transforming supposedly private spaces into quasicommunal territory. More than specific locations, however, this phenomenon entailed a process of separation as well as the consecration of new spaces. The separation was as physical as it was ritual or spiritual, using objects of worship, ideas, or words. ${ }^{44}$ In the 1720 in Madrid, for example, the house of Francisco de Córdoba was called the "synagogue" because of the status of Francisco, whose father had been condemned by the Inquisition. Francisco was known as the

41 Carsten L. Wilke ("Un judaïsme clandestin," 288) stresses that they seem to know the biblical names of the feasts but they don't know the corresponding rites.

42 McClain, Lest We Be Damned, 51.

43 "Las casas de los cristianos eran sus Iglesias en la primitiva Iglesia y parroquias de otros; y en Inglaterra, las de los católicos." Luisa de Carvajal y Mendoza, Epistolario y poesías (Madrid: Atlas-Biblioteca de Autores Españoles, 1965), 339 [letter 137].

McClain, Lest We Be Damned, 61. 
"rabbi," and even as the "principal rabbi of Spain" elected by an assembly, which, allegedly, was confirmed in Livorno afterwards. ${ }^{45}$ Accordingly, the functions attributed to Francisco and his aura ensured the sacred character of his home, almost regardless of its actual use as a place of worship. Similarly, Southwell, in A Shorte Rule of Good Life, appealed for the consecration of the home in one's mind, a spiritual exercise also conducted in the vicinity of the house, "in the walkes, gardens and orchardes [...] and so make my walkes as it were shorte pilgrimages to visite such Saints as are patrons of the place I go unto."46

Secret places of worship were not limited to houses, however. Other familiar spaces were constructed by networks of solidarity and religious sociability and nurtured by forms of concentration, both in the close-knit social fabric of the cities and the looser weaving of the social organization in rural areas. Demographic concentration could lead to the privatization of certain public spaces. This spatial appropriation was made possible by both cohabitation and spatial grouping as well as by the trajectories of individuals who circulated within the territory such as missionary priests and women fasters. The Spitalfields neighborhood in London functioned as a Recusant district: families from East Anglia had their London homes there, some of which were built on the sites of the Priory and the Augustine Saint Mary Hospital. There were clandestine chapels, and there were scribes to keep them supplied with religious texts. There were also priests, among them Henry Garnet and Robert Southwell, who installed his clandestine printing presses in the home of the Countess of Arundel. ${ }^{47}$

Although meetings were easier to organize in the countryside, the interstitial spaces of the city ("free places" as Erving Goffman called them ${ }^{48}$ ) also allowed meetings that brought together people from outside the family. These transitional zones included spaces at the edge of the city or vacant plots of land that could sometimes be appropriated for religious purposes or social gatherings. Such spaces allowed closer contact with nature-Marrano rituals, for example, often involved observing the sun or the stars—outside the family

45 AHN INQ, Legajo 157 (11) and BNE Ms. 9304, quoted in Michael Alpert, "The Secret Jews of 18th-Century Madrid," Revue des Études Juives 156 (1997): 153-54, and Rafael de Lera García, "La última gran persecución inquisitorial contra el criptojudaísmo: el tribunal de Cuenca, 1718-1725," Sefarad 47 (1987): 93.

46 Southwell, $A$ Short Rule of Good Life, 131.

47 Nancy Pollard Brown, "Paperchase: The Dissemination of Catholic Texts in Elizabethan England," in English Manuscript Studies, 1100-1700, ed. Peter Beal and Jeremy Griffiths (Oxford: Basil Blackwell, 1989), 1: 122-33.

48 Erving Goffman, Asylums: Essays on the Social Situation of Mental Patients and Other Inmates (New York: Anchor Books, 1961), 230-38. 
circle in order to enter the community's territory. These collective practices were often held in gardens, including one belonging to Pedro Onofre Cortés beyond the walls of Palma de Majorca. Cortés was convicted of crypto-Judaism in 1679 and condemned to be burned at the stake in 1691. Crypto-Jews apparently met regularly in his garden in the 1670 s to share meals or to celebrate major Jewish holidays. That is why, on 16 April 1679, the Inquisition salted the garden soil the very same day of the auto-da-fé when Pedro was reconciled. A column was erected that bore a plaque stating "year 1679. The garden was leveled, plowed, and sown with salt by order of the Holy Inquisition, because the Law of Moses was taught here. May no one ever remove or touch this column on pain of excommunication."49

Some spaces also enjoyed legal privileges that allowed a certain degree of freedom, such as the chapels in certain royal properties, including the chapels belonging to Henriette Marie de France, Charles I's wife, and Catherine de Bragance, Charles II's wife. The London embassies of Catholic countries such as France, Spain, the Kingdom of Sardinia, or the Republic of Venice served as refuge in which Recusants could worship. ${ }^{50}$ The Inns of Court in London were similarly immune to the local jurisdiction and reportedly contained their own chapels. Although there was no known equivalent of such spaces for Marranos, it seems that inns functioned in a similar way, in particular a category of Spanish posadas called secretas (as opposed to públicas) that were not required to register guests, thus permitting a certain level of secrecy and discretion. The small size of these inns and the comings and goings of travelers helped create semi-public locations where people enjoyed a form of invisibility. For example, when he was staying in Medina de Rioseco in November 1649, Vasco Fernández, a converso trader from Andujar, conversed about the Mosaic Law with another Portuguese merchant, Simon Rodríguez de Silva, from Málaga. At the time, they were both sojourning in the mesón de la Cabeza del ozo. Vasco also declared that he observed how Rodríguez de Silva's brother, Manuel, celebrated the Judaic rites on Friday evenings and Saturdays, during the three weeks they were living together in the mesón del Toro, in Andujar, on

49 Archivo General Histórico de Palma de Mallorca, Anales judaicos de Mallorca (1847), quoted in Juan de la Puerta Vizcaíno, La sinagoga balear ó historia de los judios de Mallorca (Valencia: Vicente Civera, 1857), 1: 61, and Angela Selke, Los chuetas y la Inquisición. Vida y muerte en el ghetto de Mallorca (Madrid: Taurus, 1972), 80-81.

5o Dolan, "Gender and the 'Lost' Spaces," 648-51; William Raleigh Trimble, "The Embassy Chapel Question, 1625-166o," The Journal of Modern History 18 (1946): 97-107; and Albert J. Loomie, "London's Spanish Chapel before and after the Civil War," Recusant History 18 (1987): 402-10. 
the occasion of the April 1648 fair. ${ }^{51}$ Such sites functioned as the heterotopias or "other spaces" analyzed by Foucault; "real places" established "within the very foundation of society." 52

The physical body was the holy space par excellence for secret religious communities, probably because it enshrined the most intimate spaces. The consecration of rooms in homes to specific saints, as recommended by Southwell, was extended to the human body, which, through an imaginative leap, "shall represent unto me some vertew or some vice: so that when I see them I may in one remember and practise humility, in an other patience." ${ }^{53}$ The sacred investment of the body was generally interpreted as suggesting a sense of austerity, which was expressed through the Recusants' penances and the Marranos' fasts - whose effectiveness was judged by the degree of physical weakness suffered by those who were fasting. Like the body, certain practices and objects were singled out by clandestine life, such as rosaries and holy water among Recusants, and food and candles for Marranos. But while in such cases, this implied the intensification of their pre-existing sacred dimension, certain other profane objects were consecrated by the process of ritualization itself. Indeed, any element of everyday life could become a potential "source of religious energy," to use Durkheim's words, ${ }^{54}$ that had only to be activated, such as the wicks of the candles that Marranos lighted on Friday evenings. For instance, María González, from Badajoz, declared in 1653 that she had learned that:

These wicks were manufactured when one was fasting, on Friday morning, and the woman who had to make them was seated [...] with the twine upon her skirt, from which she drew seven strands (because it had to be made of twine and not of fabric) for the Friday evening, and for each strand that was to be pulled, she held it in her hand, but without putting it with the others, and the following prayer was said: "Be blessed, Adonay, King of Kings, Lord of Lords [...] who made this wick for the holy night of Saturday at night" [...] and the person who made them asked

\footnotetext{
$5^{1}$ AHN INQ, Book 1112, fols. 5V-7r.

52 Michel Foucault, "Dits et écrits 1984. Des espaces autres. Hétérotopies (Conférence au Cercle d'études architecturales, 14 mars 1967)," Architecture, Mouvement, Continuité 5 (1984): 46-49.

53 Southwell, $A$ Short Rule of Good Life, 134.

54 Emile Durkheim, Les Formes élémentaires de la vie religieuse. Le système totémique en Australie (Paris: PUF, 1968 [1912]), 599.
} 
God whatever she desired. And once the prayer was recited seven times, it was repeated for each of the seven strands that were pulled. ${ }^{55}$

The precision of the movements and the scrupulous respect of their sequence counted as much as the prayers themselves, because it was the multiplication of the gestures that sacralized the items. Conversely, some instruments of worship such as the communion wafer and communion bread of our earlier examples, or pork for the Marranos, served as negative poles that accentuated the sacredness of their positive counterparts.

The power of these items could actually increase by the aura of orthodoxy and the prestige of the diaspora independently of their ritual function. Exiles were well aware of this, including a refugee in Louvain named Thomas Stuckley who sent some crucifixes to England after he had had them blessed by the Pope. It was sufficient for a Recusant to look at one of the crucifixes with devotion to earn fifty days of indulgence. ${ }^{56}$ There is some question as to whether the redemptive power of the indulgences was transferrable by virtue of the contagious nature of sacredness. In fact, any object from the diaspora, such as books, provided the impression of being in proximity to Judaism or Catholicism, and thus to the purity of orthodoxy. Even the tiniest fragment or artifact could become an amulet useful for many ritual purposes. In the 1570s, this was the case of a piece of paper that Diego de San Juan, from Baeza, in Andalusia, received from a soldier in Italy. Each of his six sisters had a copy of the paper, which was described in highly varied ways at the inquisitional tribunal in Córdoba in 1572. One sister asserted that the page held "the names of the Messiah, Emmanuel, and God's other names in Hebrew."57 It is difficult to capture the Hebrew, Greek, and Latin resonances of the words on the page from the phonetic transcription made by the inquisitional notary, but what is most significant is how the San Juan sisters used the sacred document. One

55 “Ásense las dichas torcidas estando en ayunas por la mañana en los viernes y estando sentada la mujer que las ha de hacer [... y teniendo estopa sobre las faldas se saca la dicha estopa siete perpellones della (porque no se ha de hacer de lienzo sino de estopa) para el dicho viernes en la noche y que en cada perpellón que se saca teniéndole en la mano sin juntarle con los demás se dice la oración siguiente: 'Bendito tu Adonaï, Rey de los Reyes [...] que hiciese esta torcida sancta para la noche sancta del santo sabado' [...] y prosigue la persona que la hace y pide a Dios lo que quiere. Y dicha la oracion siete veces se repite en cada uno de los siete perpellones que se saca," in AHN INQ, Book 1117, quoted in Pilar Huerga Criado, En la raya de Portugal. Solidaridad y tensiones en la comunidad judeoconversa (Salamanca: Universidad de Salamanca, 1993), 182-83.

56 McClain, Lest We Be Damned, 37.

57 AHN INQ, Legajo 1856 (11), fol. 14v printed in Rafael Gracia Boix, Autos-da-féy causas de la Inquisición de Córdoba (Córdoba: Diputación Provincial de Córdoba, 1983), 134. 
of them explained that the soldier had instructed her brother that "by bearing this paper with him, he would be protected from his enemies," while she herself, "believing that they were God's names in the Law of Moses, often recited them, and when some of her brothers were ill, pronounced them in order to cure them." 58

This paper served as a talisman whose power was an outgrowth of its content, but also of the fact that it originated in the diaspora. This ensured that the document could serve an infinite variety of purposes and be adapted to the varying practices of the group, like the relics and body parts of people perceived as martyrs and venerated, which all became religious focal points that created a sense of community identity. This was made possible, in turn, by the fact that the culture of martyrdom, like in other religious minorities, filled the imaginaries and practices of Recusants and Marranos alike.

It is no surprise that a sense of martyrdom developed in groups that were subjects of repression over long periods of time..$^{59}$ This included the Marranos, who were profoundly influenced by Catholicism. While the Recusants linked their sufferings with the early Christian martyrs, ${ }^{60}$ including Christ and the Apostles to whom they, as a result, felt closer, the Marranos identified with the Hebrews enslaved by pagans. They conferred an aura of victimhood that was even echoed in anti-Jewish treatises such as the anonymous Verdades catholicas contra ficçiones Judaicas, origen de la Jente de la naçion Hebrea (c. 1637-1639): "People condemned by the Holy Office are assisted by alms, with the oldest designating those who were the most valiant to deny, as are those who carry the insignia of fire and who only confessed at the last moment, they integrate them into their affairs and commissions so that no one needs to beg;

$5^{8} \quad$ "Trayendo aquel papel consigo sería liberado de sus enemigos," while she, "entendiendo que eran nombres de dioses en la ley de Moisés los rezaba muchas veces y cuando habia algunos de sus hermanos enfermos se los decian para que sanasen." AHN INQ, Legajo 1856 (11), fols. $12 \mathrm{r}, 14 \mathrm{r}-\mathrm{v}$ and $16 \mathrm{r}$, printed in ibid., 132, 134, and 136 .

59 There is a vast literature on early modern English martyrdom: Alice Dailey, The English Martyr from Reformation to Revolution (Notre Dame: University of Notre Dame Press, 2012); Thomas S. Freeman and Thomas F. Mayer, eds., Martyrs and Martyrdom in England, c. 1400-1700 (Woodbridge: Boydell Press, 2007); Susannah Monta, Martyrdom and Literature in Early Modern England (Cambridge: Cambridge University Press, 2005).

60 See for instance Persons's Letter to Agazzari, printed in Hicks, ed., Letters and Memorials, 86: "The Catholics in various parts of their houses have a number of secret places (as we read was the custom in the primitive church)." 
because neither begging, nor the sambenitos are offenses in their eyes; furthermore, those who have a sambenito are held in the greatest esteem and they want them to be husbands to their daughters." ${ }^{\prime 61}$

The singularity of this culture of martyrdom, beyond the fact that it defined their imaginaries and how they constructed their sense of identity, stems from the fact that it formed the core of their relationship to the diaspora. Indeed, it built a shared culture and a collective memory that connected them to the Homeland, the front line of the Faith, and to the scattered members of the diaspora in order to shape an "imagined community." This justified the circulation of missionaries, texts, and ritual objects, despite the criticisms of their practices of simulation and dissimulation. The captivity of the Recusants and the Marranos, who experienced oppression and lived in clandestinity, is interpreted in Messianic terms, with their suffering bearing witness to the Election of the new Israel and to the oncoming end of time. These martyrs are portrayed in frescoes by Circignani, also known as Pomarancio, that were distributed via engravings from 1584 onward, and that covered the walls of the church of the English College in Rome. The frescoes were particularly striking because of their realistic depictions of suffering. In the center of the Church stood the "painting of the martyrs," painted by Durante Alberti in 1581 when the seminary was founded. This painting represents the Trinity, with the blood of Christ flowing over a map of Great Britain, surrounded by the earliest martyrs-Saint Thomas of Canterbury and Saint Edmund. The frescoes imbued seminary students with the spirit of sacrifice and the "purity of martyrdom." 62

Further support for this culture of martyrdom was contained in the martyrologies written and usually published by diaspora communities that celebrated the victims of the repression in Spain and in England. ${ }^{63}$ In the Nação, there was the Romance al divin Mártir Juda Creyente, martirizado en Valladolid, which was written in memory of Lope de Vera, the archetypal Marrano martyr, around 1648 in Amsterdam by Antonio Enríquez Gómez, who later died in the prisons of the Inquisition in Seville in $1663 .{ }^{64}$ Another Marrano martyr narrative was the Contra la Verdad no hay Fuerça. Panegírico a los tres

61 BNE, Ms. 18756 , fol. 6 r.

62 Dillon, The Construction of Martyrdom, 172-227; Carol M. Richardson, "Durante Alberti, the Martyrs' Picture and the Venerable English College, Rome," Papers of the British School at Rome 73 (2005): 223-63; and Anthony Kenny, "From Hospice to College," in The English Hospice in Rome, ed. John Allen (Leominster: Gracewing, 2005 [1962]), 218-73.

63 See Miriam Bodian, Dying in the Law of Moses. Crypto-Jewish Martyrdom in the Iberian World (Bloomington: Indiana University Press, 2007).

64 Israël S. Révah, Antonio Enríquez Gómez. Un écrivain marrane (v. 16oo-1663), ed. Carsten L. Wilke (Paris: Chandeigne, 2003). 
bienaventurados mártires Abraham Athias, Yahacob Rodrigues Caseres et Raquel Nuñez Fernandez que fueron quemados vivos en Cordova por santificar la unidad divina (1665), written by Miguel (alias Dani Levi) de Barrios, the well-known Amsterdam writer exiled from Andalusia. In this text, he celebrated the "sacrifice" of the seventy-five-year-old Jorge Méndez de Castro, father of the Amsterdam printer Josef Athias, of Domingo Rodríguez de Cáceres, a trader from Plasencia, and of Leonor María (Núñez) Enríquez, a young woman from Utrera, whose agony had touched the audience of the auto-da-fé.

The martyrologies were far more numerous among Catholics and were sometimes illustrated. They were usually published in the form of annual calendars of religious celebrations and were originally written in English or Latin - and sometimes in Spanish-but were quickly translated. Two such titles included A Brief History of the Glorious Martyrdom of XII Reverend Priests [...], executed within these twelve monthes for confession and defence of the catholike faith [...], written by Cardinal William Allen (who founded the first missionary-college in Douai in 1568) in Rheims in 1582, and A catalogue of martyrs in England: for profession of the Catholique faith, since the yeare of our Lord, 1535 [...], composed in Douai in 1608 by Thomas Worthington, the head of the College of Douai. In addition to published examples, a far greater number of handwritten texts were undoubtedly created locally, particularly among Recusants. These texts contained narratives that were often filled with supernatural elements that presented martyrdom as a gift from God and a high privilege. Such stories could be read aloud and commented upon, which rendered them highly accessible and ensured their role as important vectors of the group cohesion. ${ }^{65}$

Under these circumstances, it is understandable that relics such as human remains or objects that had belonged to martyrs took on great value in Recusant, Marrano, and diasporic communities. Such artifacts represented the group memory by making the sacrifices of the martyrs actual and immediate, legitimating their resistance and ensuring the group's survival. These relics were even included in ceremonies given their power of intercession, which was supported by accounts of miracles that grew richer in details as they were repeated. ${ }^{66}$ Executions of missionary priests thus supplied Recusants with an inexhaustible supply of relics that were precious both for their simultaneity in time and place and connotations of shared experience. Written accounts

65 Dillon, The Construction of Martyrdom, 99-101 and 375-97.

66 See, inter alia, Alexandra Walsham, ed., Relics and Remains, Past \& Present, 206, suppl. 5 (Oxford, 2010), and Pierre-Antoine Fabre, Philippe Boutry and Dominique Julia, eds., Corps saints, lieux sacrés. Le culte des reliques à l'époque moderne (Paris: Éditions de l'EHESS, 2009). 
describing the details of the auto-da-fés in Spain, as well as the ashes scooped from the stakes, spread throughout the Nação in similar way. One witness told the Inquisition that "when the Holy Office celebrated the great auto-da-fé [in Madrid in July 1632] four or five years ago, [he] learned that a box containing the ashes of those who were burned had been sent as relics [por reliqueas] to the Jewish community in Amsterdam." Another witness, Manuel Fernandez, explained that the ashes were sent to Rouen "and to other places." ${ }^{77}$ We nevertheless ignore if other remains such as hair and clothes were also collected in Spain, as it was the case in England.

Executions obviously provided the opportunity for the condemned to be heroic, to the great discontent of the authorities responsible for repressing them, naturally. But their communities "glorified" their death and wrote to disseminate their stories, particularly when they included miraculous events. This accounts for the circulation of the last words of Edmund Campion in 1582, which were duly recorded and quickly printed in London. Execution sites and the ceremonies surrounding them were elaborately staged by the authorities, adding to a sense of group cohesion and religious identity. Such events, especially in the English case, provided opportunities for groups to express their faith more openly than customary, thanks to the protection offered by the crowd, forming a quasi-mystical circle. Indeed, the execution sites were special community spaces that extended to the city via the procession of the condemned through the streets. For crypto-Catholics, these processions that celebrated martyrs could also be seen as the stations of the cross. Dozens of Catholics followed the condemned, ritualizing their connection to the martyrs, praying for and with them and touching them to profit from their power for divine intercession, receiving blessings or removing pieces of clothing to be turned into relics. ${ }^{68} \mathrm{John}$ Cecil stated to Robert Persons, in 1594, that "three hundred ladies and women of good position [...] all with black hoods" followed John Boste to the gallows in Durham, "as the Marys did for Christ" they said (a probable reference to Mary and Mary-Magdalene). ${ }^{69}$ Beyond this kind of learning-by-example, these executions supplied elements that were integrated into worship ceremonies, whether through readings from the Inquisition's edictos de fé, accusations or sermons that the English priests gave from the gallows. When Thomas Bullaker preached in October 1642, one witness reported that his sermon "penetrated

67 AHN INQ, Book 1102, fols. 2v-3r and 4v.

68 McClain, Lest We Be Damned, 76-82, 84, 157-59, 161, 163-67 and "Without Church, Cathedral, or Shrine: The Search for Religious Space among Catholics of England, 15591625," The Sixteenth Century Journal 33 (2002): 392-97.

69 Printed in John H. Pollen, Unpublished Documents relating to the English Martyrs (London: Catholic Record Society, 1908), 1: 285-86. 
many a heart, and greatly affected even the hardened heretics. ${ }^{70}$ The actual execution sites could also be perceived as sacred, generating pilgrimages, as the Recusants did with Tyburn in London. ${ }^{71}$

\section{5}

\section{Conclusion}

In the introduction to this essay, Catarina Fernandes was reported to have hidden her communion wafer, and Elizabeth Coulson her communion bread. These acts meant not only a rejection of the Catholic conception of incarnation, but they also reflected shared religious practices. The many similarities between Recusants and Marranos that this comparison has brought to light clearly demonstrate that these two secret communities functioned in similar ways. Their rituals were flexible and marked by a close attention to gestures as well as the diversity of sources of what they considered sacred. New practices and objects that were crucial for maintaining the group's cohesion could be validated by diasporic belief systems. Nevertheless, rituals coexisted with the emphasis placed on interiority and intentionality that permitted a form of individual creativity that spread throughout the diaspora. This included the spiritualization of consecration, symbolized by the process described by Robert Southwell intended for English Catholics, as well as the quasi-ethnic interpretation of Judaism among the Marranos, which suggests a sense of belonging that goes beyond ritual. Besides, this back-and-forth movement between new religious needs and secret practices, and their validation by the normative authorities in exile, produced a constant creative process. Therefore, despite the criticisms that simulation and dissimulation prompted, these secret communities functioned as significant vectors of change in how their entire religious groups practiced their faiths. It is evident that these communities were as diverse and changeable as their rituals. But this diversity and adaptability leads to draw a difference between what it means to belong to a community defined by faith and actual religious practices. It also suggests the need for a more social understanding of religious communities.

70 Quoted in Timothy J. McCann, "Some Unpublished Accounts of the Martyrdom of Blessed Thomas Bullaker, OSF, of Chichester in 1642," Recusant History 19 (1988): 174 and 179. 


\section{Bibliography}

Allison, Antony Francis, and David Morrison Rogers. A Catalogue of Catholic Books in English Printed Abroad or Secretly in England, 1558-1640. Bognor Regis: Arundel Press, 1956.

Alpert, Michael. "The Secret Jews of 18th-Century Madrid." Revue des Études Juives 156 (1997): 135-171.

Anzieu, Didier. Le groupe et l'inconscient: l'imaginaire groupal. Paris: Dunod, 1999 [1975].

Aveling, John Cedric H. Catholic Recusancy in the City of York, 1558-1791. London: Catholic Record Society, 1970.

Aveling, John Cedric H. The Handle and the Axe: The Catholic Recusants in England from Reformation to Emancipation. London: Blond and Briggs, 1976.

Bodian, Miriam. Dying in the Law of Moses. Crypto-Jewish Martyrdom in the Iberian World. Bloomington: Indiana University Press, 2007.

Bodian, Miriam. "Hebrews of the Portuguese Nation: The Ambiguous Boundaries of Self-Definition.” Jewish Social Studies 15, no. 1 (2008): 6f6-80.

Bodian, Miriam. “Men of the Nation': The Shaping of Converso Identity in Early Modern Europe." Past and Present 143 (1994): 48-76.

Bossy, John. The English Catholic Community, 1570-1850. London: Darton, Longman \& Todd, 1975 .

Boyajian, James C. Portuguese Bankers at the Court of Spain, 1626-1650. New Brunswick, NJ: Rutgers University Press, 1983.

Brubaker, Rogers, and Frederick Cooper. "Beyond 'Identity'. In Ethnicity without Groups. Edited by Rogers Brubaker, 28-63. Cambridge, MA: Harvard University Press, 2004.

Caro Baroja, Julio. Los judios en la España moderna y contemporanea. 3 vols. Madrid, ISTMO, 2000 [1961].

Carrasco, Rafael. "Inquisición y judaizantes portugueses en Toledo (segunda mitad del siglo XVI)." Manuscrits 10 (1992): 41-60.

Carrasco, Rafael. "Preludio al 'Siglo de los portugueses.' La Inquisición de Cuenca y los judaizantes lusitanos en el siglo XVI." Hispania 47 (1987): 503-59.

Contreras, Jaime. “Criptojudaísmo en la España moderna. Clientelismo y linaje." Areas 9 (1988): 77-100.

Dillon, Anne. The Construction of Martyrdom in the English Catholic Community, 15351603. Aldershot: Ashgate, 2002.

Dolan, Frances E. "Gender and the 'Lost' Spaces of Catholicism." The Journal of Interdisciplinary History 32 (2002): 641-65.

Durkheim, Emile. Les Formes élémentaires de la vie religieuse. Le système totémique en Australie. Paris: PUF, 1968 [1912]. 
Fabre, Pierre-Antoine, Philippe Boutry, and Dominique Julia, eds. Corps saints, lieux sacrés. Le culte des reliques à l'époque moderne. Paris: Éditions de l'EHESS, 2009.

Ferguson, Elizabeth. "The Role of Women in the Survival of Catholicism in Post-Reformation Lancashire and Yorkshire, 1559-1603." Master's thesis, Carleton University, Ontario, 2006.

Foucault, Michel. "Dits et écrits 1984. Des espaces autres. Hétérotopies (Conférence au Cercle d'études architecturales, 14 mars 1967)." Architecture, Mouvement, Continuité 5 (1984): 46-49.

Gitlitz, David M. Secrecy and Deceit. The Religion of the Crypto-Jews. Albuquerque: University of New Mexico Press, 2002 [1996].

Goffman, Erving. Asylums: Essays on the Social Situation of Mental Patients and Other Inmates. New York: Anchor Books, 1961.

Gracia Boix, Rafael. Autos-da-fé y causas de la Inquisición de Córdoba. Córdoba: Diputación Provincial de Córdoba, 1983.

Graizbord, David L. "Religion and Ethnicity Among 'Men of the Nation': Toward a Realistic Interpretation." Jewish Social Studies 15, no. 1 (2008): 32-65.

Graizbord, David L. Souls in Dispute: Converso Identities in Iberia and the Jewish Diaspora, 1580-1700. Philadelphia: University of Pennsylvania Press, 2004.

Hernández Franco, Juan. "El pecado de los padres: construcción de la identidad conversa en Castilla a partir de los discursos sobre limpieza de sangre." Hispania, 64 (2004): 515-42.

Hicks, Leo, ed. Letters and Memorials of Father Robert Persons, SJ. Vol. 1 (to 1588). London: Catholic Record Society, 1942.

Holmes, Peter. Resistance and Compromise. The Political Thought of the Elizabethan Catholics. Cambridge: Cambridge University Press, 1982.

Huerga Criado, Pilar. En la raya de Portugal. Solidaridad y tensiones en la comunidad judeoconversa. Salamanca: Universidad de Salamanca, 1993.

Kagan, Richard L and Philip D. Morgan, eds. Atlantic Diasporas: Jews, Conversos, and Crypto-Jews in the Age of Mercantilism, 1500-180o. Baltimore: The Johns Hopkins University Press, 2008.

Kenny, Anthony. "From Hospice to College." In The English Hospice in Rome. Edited by John Allen, 218-73. Leominster: Gracewing, 2005 [1962].

Lake, Peter, and Michael Questier. The Antichrist's Lewd Hat. Protestants, Papists \& Players in Post-Reformation England. New Haven: Yale University Press, 2002.

Lake, Peter, and Michael Questier. The Trials of Margaret Clitherow. Persecution, Martyrdom and the Politics of Sanctity in Elizabethan England. London-New York, Continuum, 2011.

Lera García, Rafael de. "La última gran persecución inquisitorial contra el criptojudaísmo: el tribunal de Cuenca, 1718-1725." Sefarad 47 (1987): 87-137. 
Levine Melammed, Renée. Heretics or Daughters of Israel? The Crypto-Jewish Women of Castile. Oxford: Oxford University, 1999.

Loomie, Albert J. "London's Spanish Chapel before and after the Civil War." Recusant History 18 (1987): 402-10.

López Belinchón, Bernardo J. Honra, libertad y hacienda (Hombres de negocios y judíos sefardies). Alcalá de Henares: Universidad de Alcalá, 2001.

McCann, Timothy J. "Some Unpublished Accounts of the Martyrdom of Blessed Thomas Bullaker, OSF, of Chichester in 1642." Recusant History 19 (1988): 171-82.

McClain, Lisa. Lest We Be Damned. Practical Innovation and Lived Experience among Catholics in Protestant England, 1559-1642. New York-London: Routledge, 2004.

McClain, Lisa. "Without Church, Cathedral, or Shrine: The Search for Religious Space among Catholics of England, 1559-1625." The Sixteenth Century Journal 33 (2002): 392-97.

Meyers, Charles, and Norman Simms, eds. Troubled Souls: Conversos, Crypto-Jews, and Other Confused Jewish Intellectuals from the Fourteenth through the Eighteenth Century. Hamilton: Outrigger Publishers, 2001.

Muchnik, Natalia. "Being Against, Being With: Marrano Self-Identification in Inquisitorial Spain (16th-18th c.). An Essay." Jewish History 25 (2011): 153-74.

Muchnik, Natalia. "De la ville inquisitoriale à la ville de tolérance: identités féminines judaïsantes en Europe occidentale (XVII ${ }^{\mathrm{e}}$ siècle)." Annales de Bretagne et des pays de l'Ouest 113 (2006): 29-42.

Muchnik, Natalia. De paroles et de gestes. Constructions marranes en terre d'Inquisition. Paris: Éditions de l'EHESS, 2014.

Mullet, Michael, ed. English Catholicism:1680-1830. 6 vols. London: Pickering \& Chatto, 2006.

Netanyahu, Benzion. The "Marranos" of Spain from the Late XIVth to the Early XVIth Century. New York: American Academy for Jewish Research, 1966.

Netanyahu, Benzion. The Origins of the Inquisition in Fifteenth-Century Spain. New York: Random House, 1995 .

Pike, Ruth. Linajudos and Conversos in Seville. Greed and Prejudice in Sixteenth-and Seventeenth-Century Spain. New York: Peter Lang, 2000.

Pollard Brown, Nancy. "Paperchase: The Dissemination of Catholic Texts in Elizabethan England." In English Manuscript Studies, 1100-1700. Edited by Peter Beal and Jeremy Griffiths, 1: 122-33. Oxford: Basil Blackwell, 1989.

Pollen, John H. Unpublished Documents Relating to the English Martyrs. London: Catholic Record Society, 1908.

Puerta Vizcaíno, Juan de la. La sinagoga balear ó historia de los judíos de Mallorca. Valencia: Vicente Civera, 1857.

Questier, Michael. "Conformity, Catholicism and the Law." In Conformity and Orthodoxy in the English Church, c. 1560-166o. Edited by Peter Lake and Michael Questier, 237-62. Woodbridge: Boydell, 2000. 
Questier, Michael. Conversion, Politics, and Religion in England, 1580-1625. Cambridge: Cambridge University Press, 1996.

Raleigh Trimble, William. “The Embassy Chapel Question, 1625-166o." The Journal of Modern History 18 (1946): 97-107.

Révah, Israël S. Antonio Enríquez Gómez. Un écrivain marrane (v. 160o-1663). Edited by Carsten L. Wilke. Paris: Chandeigne, 2003.

Révah, Israël S. Des marranes à Spinoza. Paris: Vrin, 1995.

Richardson, Carol M. "Durante Alberti, the Martyrs' Picture and the Venerable English College, Rome." Papers of the British School at Rome 73 (2005): 223-63.

Rowlands, Mary. "Recusant Women (1560-1608)." In Women in English Society, 1500180o. Edited by Mary Prior, 114-15. London: Methuen, 1985 .

Saraiva, António J. The Marrano Factory. The Portuguese Inquisition and Its New Christians, 1536-1765. Leiden: Brill, 2001.

Schreiber, Markus Marranen in Madrid, 16oo-167o. Stuttgart: Franz Steiner, 1994.

Selke, Angela. Los chuetas y la Inquisición. Vida y muerte en el ghetto de Mallorca. Madrid: Taurus, 1972.

Shell, Alison. Catholicism, Controversy and the English Literary Imagination, 1558-1660. Cambridge: Cambridge University Press, 1999.

Sicroff, Albert. Les controverses des statuts de pureté de sang en Espagne. Paris: Didier, 1960.

Simmel, Georg. "The Sociology of Secrecy and of Secret Societies." American Journal of Sociology 11 (1906): 441-98.

Southern, Alfred C. Elizabethan Recusant Prose, 1559-1582. A Historical and Critical Account of the Books of the Catholic Refugees Printed and Published Abroad and at Secret Presses in England together with an Annotated Bibliography of the Same. Glasgow-London: Sands, 1950.

Southwell, Robert. A Shorte Rule of Good Life. To direct the devout Christian in a regular and orderly course. Douai?, 1595.

Soyer, François. Popularizing Anti-Semitism in Early Modern Spain and Its Empire. Francisco de Torrejoncillo and the Centinela contra Judios (1674). Leiden: Brill, 2014.

Spivey Ellington, Donna. From Sacred Body to Angelic Soul. Understanding Mary in Late Medieval and Early Modern Europe. Washington, DC: Catholic University of America Press, 2001.

Wachtel, Nathan. La foi du souvenir. Labyrinthes Marranes. Paris: Éditions du Seuil, 2001.

Walsham, Alexandra. Church Papists. Catholicism, Conformity and Confessional Polemic in Early Modern England. London: Boydell \& Brewer, 1999 [1993].

Walsham, Alexandra. "England's Nicodemites: Crypto-Catholicism and Religious Pluralism in the Post-Reformation Context." In The Adventure of Religious Pluralism in Early Modern France. Edited by Keith Cameron, Mark Greengrass, and Penny Roberts, 292-94. Oxford: Peter Lang, 2000. 
Walsham, Alexandra, ed. Relics and Remains, Past \& Present, 206, suppl. 5 (Oxford, 2010).

Wilke, Carsten L. "Un judaïsme clandestin dans la France du XVII ${ }^{\mathrm{e}}$ siècle. Un rite au rythme de l'imprimerie." In Transmission et passages en monde juif. Edited by Ester Benbassa, 281-311. Paris: Publisud, 1997.

Wooding, Lucy E.C. Rethinking Catholicism in Reformation England. Oxford: Clarendon Press, 2003.

Yates, Julian. "Parasitic Geographies: Manifesting Catholic Identity in Early Modern England." In Catholicism and Anti-Catholicism in Early Modern English Texts. Edited by Arthur F. Marotti, 63-65. Houndsmills: Macmillan Press, 1999.

Yovel, Yirmiyahu. The Other Within. The Marranos: Split Identity and Emerging Modernity. Princeton, NJ: Princeton University Press, 2009. 